Lénárt-Cheng, Helga. "Lenard, Alexander. 2013. Stories of Rome (trans. Mark Baczoni). Budapest: Corvina. 241 pp." Hungarian Cultural Studies. e-Journal of the American Hungarian Educators Association, Volume 8 (2015): http://ahea.pitt.edu DOI: 10.5195/ahea.2015.197

\title{
Lenard, Alexander. 2013. Stories of Rome (trans. Mark Baczoni). Budapest: Corvina. 241 pp.
}

\section{Reviewed by Helga Lénárt-Cheng, Saint Mary's College of California}

Stories of Rome is the war memoir of Alexander Lenard (Sándor Lénárd, 1910-1972), a Hungarian-born physician and writer of German-Jewish origin. Lenard is best known as a translator (see his best-selling translation of Winnie the Pooh into Latin), but he also authored medical studies, cookbooks, memoirs, essays and poems in Hungarian, German, English, Italian and Latin. The volume at hand is the first English translation of Római történetek, which was first published in Hungary in 1969. Stories of Rome is one of Lenard's most personal works, an intimate portrait of a young writer- and poet-to-be. It is also one of the few books by Lenard available in English. The Corvina Press at Budapest chose wisely, for Stories of Rome has a truly universal appeal, as anyone interested in World War II, or in the psycho-cultural manifestations of Italian fascism, will appreciate Lenard's vivid accounts. The book is also representative of Lenard's unique style: discreet and hilarious, bitingly ironic, and warmly humanistic. The translation was ably done by the British translator Mark Baczoni, who shares Lenard's deep appreciation for the playfulness and resourcefulness of both languages (for a full list of Lenard's works in English and Hungarian see: http://mek.oszk.hu/kiallitas/lenard/indexeng.html; see also: Helga Lénárt-Cheng, “A Multilingual Monologue: Alexander Lenard's Self-Translated Autobiography in Three Languages," Hungarian Cultural Studies 7 (2014) at: http://ahea.pitt.edu).

In August 1938, while living in Vienna, Lenard fled the Anschluss of Austria by NaziGermany and found shelter in Italy, where he stayed until he left for Brazil in 1951. Although he did not mean to stay long in Italy, as his travel visa was only valid for three months, he was in no rush either. He thought of this trip as an adventure, and he waited for "things to happen like they do in dreams": "I sat down on my suitcase in one corner of the square, and waited to see what would happen. I felt that suddenly a curtain would be drawn back, and that the play I had come here from Vienna to see would begin. Some new process would start, into which I and my little suitcase would step; we would be given a part, and would speak, and be" (12). He did find himself, indeed, in the middle of a play, but the part he was given was entirely unexpected. Lenard knew that Italy, too, had a fascist leader, but he had heard that Mussolini had ulcers and was hoping that a ruptured ulcer would soon mean the end of fascism in Europe. "Those ulcers could easily rupture. The wall of the stomach is four or five millimeters thick -- perhaps that is all that separates us from peace" (12). Instead, Mussolini survived, and for seven long years Lenard had to watch and participate in the grandiose fascist play staged by the Duce.

The false bravado of Italian fascism is presented in Lenard's memoir as a farcical stage adaptation of German totalitarianism. The stage sets for the fascist parades are erected by Cinecittà, the film studio founded for propaganda purposes, and they fulfill every dream of the Duce's Caesarian imagination. Mussolini's diplomatic pirouettes and rhetorical fireworks are made highly comical in Lenard's rendering. To describe one of the grand photo opportunities, he

$(\mathrm{cc}) \mathrm{BY}$

ULLS D-Serle 
Lénárt-Cheng, Helga. "Lenard, Alexander. 2013. Stories of Rome (trans. Mark Baczoni). Budapest: Corvina. 241 pp." Hungarian Cultural Studies. e-Journal of the American Hungarian Educators Association, Volume 8 (2015): http://ahea.pitt.edu DOI: 10.5195/ahea.2015.197

writes: "The Duce jumps elegantly out of the car onto the red carpet unrolled with superhuman speed at his feet. [...] his freshly-shaved pate is that of an Emperor without his laurel wreath." "After all, posterity will want to know how it all looked. All this is for the benefit of the textbooks of the future" (67).

The Duce's show has to have spectators, of course, and in a regime where the supporters of the State belong to the minority, the Ministry of Propaganda had to be creative. To explain where they got the crowds to cheer at the parades, Lenard quotes the words of a bureaucrat: "Street-sweepers, dustmen, the people of the netezza urbana. There's eight thousand of them, if you count the bus conductors. They're the ones we call when we're not sure that the crowds will come of their own accord, or if we are sure they won't [...]" (64). Lenard describes the whole regime as a grand "Pinocchianism" wherein everyone pretends to play along but without truly believing. For example, people keep portraits of the Duce in their homes, but only because they want to have something to spit on when they get frustrated. Citizens also learn the art of interpreting propaganda. "This science," writes Lenard, "is comparable to chess theory or the higher forms of dogma. The reader reads the news, attempts to reconstruct the actual event, and from the difference between the event and the way it's presented, tries to deduce which way the political wind is currently blowing" (53).

Reading these droll descriptions we almost get the impression that Italian fascism never existed, as this operetta-like fascism seems more entertaining than dangerous. Yet Lenard's dark humor and touches of irony may just be his means of self-defense against the crippling memories he had of those years, for the role that Lenard got to play in Rome was anything but glorious, as because of his illegal status he had to endure years of homelessness and humiliating poverty. Although Lenard was a Hungarian citizen, the Hungarian consul in Rome refused to validate his passport and those of his Hungarian friends, all of whom had fled from Hungary. In the following dialogue, the consul's objections may be oblique, but they leave no doubt as to the anti-Semitic politics he represents:

'I'll need to see your parents,' and your grandparents' birth certificates, as well as baptismal certificates, and such documents as will verify their places of residence over the past fifty years $[\ldots] "$

"But your Excellency [...] I want to emigrate. We're undesirable persons. I'm asking you to make it possible for us to emigrate -- we'll go all the way to the jungle."

"Your travel plans are no concern of mine. I will only renew the passports of Hungarian citizens."

"But we are Hungarian!"

"You are not. You are persons whose native language happens to be Hungarian" (61).

Lenard does not complain about the stress he endured as a result of his illegal status, but the fear he experienced during those years seeps through these seemingly detached descriptions. The following report on the role of Italian concierges gives readers a glimpse into the menacing reality of daily life under fascism. Lenard explains: "The residents aren't afraid of the Duce, they are afraid of the concierge. The concierge is the eyes [sic] of the State. He's the one who goes through your dustbin to find out what you've been eating. He's the one to take the suspicious letter to the police. He is the representative of the totalitarian State" (106). Within this "conciergetocracy" (106), Lenard, too, begins to internalize the State's paranoid fears and 
suspicions. As an illegal immigrant he cannot practice his medical profession, so he begins to measure blood pressure in pharmacies and at people's homes. Soon he realizes that his barometer in its heavy leather box looks like a bomb, and that his little black-notebook records of names, addresses, and blood pressure measurements of his patients might look like a conspirator's network list. He then projects his fears onto his own concierge and begins to ask himself, with a nagging sense of guilt, questions like: "What if I really am walking around with a bomb? What if I am the conspirator-in-chief? I look at people's faces -- have they recognized me? I think about what I would say at the police station [...]" (104).

Lenard's internalization of the State's paranoia signals a shift in the narrative, because after a while Lenard's character no longer has the luxury of simply observing life in Rome, like a tourist, as he begins to suffer all the hardships of war together with the locals. By the end of the memoir he becomes a member of the local Resistenza, privy to the city's well-guarded secrets. Accordingly, the structure of the memoir also reflects these gradual changes in his status: the first part entitled "Rome 1938" recounts the events of the first five months following Lenard's arrival, while the second part, "Rome 1943," describes the five days in September 1943 when Italy surrendered to the Allies. Although both these accounts were written retrospectively in the 1950s and 1960s, they are steeped in the urgency of the present moment. As a memoirist, Lenard is highly conscious of his role as a witness of a historical moment, even though he warns readers and historians against "the naïve assumption that [they] will be able to unravel the mysteries of bygone eras from within" (137).

To become a Hungarian writer, more precisely, to be acknowledged as a Hungarian writer, was a lifelong dream of Lenard. When his first books appeared in Hungary in the 1960s, they were published under the name "Alexander Lenard" (instead of Lénárd Sándor); this made readers think he was a foreign author translated into Hungarian, which caused Lenard great chagrin. As he wrote to a friend: "You can imagine me like a king from the fairy tales who weeps out of one eye and laughs out of the other. I laugh because after half a century, and just in time before I die, I managed to fulfill my one true dream: I never wanted anything else than to write a Hungarian book. I weep, however, seeing that my name became 'Alexander Lenard'!" (See György G. Kardos, "Ember a világ végén" ['Man at the End of the World'] - Foreword to Sándor Lénárd's Völgy a világ végén s más történetek ('A Valley at the End of the World and Other Stories'), Budapest: Magvető, 1973. In a way, this 2013 English edition of Stories of Rome, published with "Alexander Lenard" as the author's name on the cover, repeats this offense. But one could also argue that those second or third generation Hungarians who can no longer access Lenard's/ Lénárd's books in Hungarian are precisely the readers who will most appreciate the tribulations of this lone writer. 